\title{
An Assessment for Energy Management in Retail Stores
}

\author{
Zheng $\mathrm{Ma}^{1}$, Joy Dalmacio Billanes ${ }^{2}$ and Bo Nørregaard Jørgensen ${ }^{2}$ \\ 1. Center for Healthcare Informatics and Technology, University of Southern Denmark, Odense 5230, Denmark \\ 2. Center for Energy Informatics, University of Southern Denmark, Odense 5230, Denmark
}

\begin{abstract}
Retail stores are responsible for large energy consumption, which requires more intensified action to improve energy efficiency. Effective energy management can improve energy efficiency in retail stores. However, it is a challenge to implement energy management in retail stores due to different stakeholders' roles and diverse store features. Literally, technical and management aspects of energy management have received much attention in research. However, limited studies systemically investigate internal and external factors and stakeholders' involvement in the energy management of retail buildings. With multi-cases in the Philippines, this paper examines the energy profiles in retail stores and develops an assessment for energy management in retail stores. The assessment includes store features, internal and external stakeholders, climate, electricity price and grid condition, energy consumption, and management. The assessment can assist retail stores to develop their energy management plans with their store profile.
\end{abstract}

Key word: Energy consumption, energy management, impact factors, retail stores, stakeholder involvement, store features.

\section{Introduction}

Buildings (e.g. residential, commercial and industrial) are responsible for $40 \%$ of overall energy consumption [1]. Commercial buildings take an important role in the energy consumption [2]. In China, commercial buildings are the largest consumer of energy [3]. The energy efficiency of commercial buildings becomes more and more important due to the increasing number of new commercial construction each year. For instance, store buildings take the highest percentage of the most newly constructed buildings in the Philippines, which accounts for 4,074 buildings from 2012-2015 [4-7] (shown in Fig. 1).

There are different building technologies installed in commercial buildings, such as space heating, cooling, ventilation, water heating, lighting, and refrigeration. In countries with a tropical climate like in the Philippines, consider air-conditioning units as the most energy consuming appliances in commercial

Corresponding author: Zheng Ma, Ph.D., associate professor, research fields: business ecosystem simulation and business modelling for the smart energy and healthcare system. buildings [8]. In addition, refrigeration is responsible for about $40-50 \%$ of the total electricity consumption in the supermarkets $[9,10]$.

High electricity consumption and building technologies enable commercial buildings to participate in energy efficiency and flexibility programs (e.g. load shedding) [11]. Meanwhile, technical solutions for energy efficiency and flexibility in commercial buildings have received much attention in research. For example, there are studies of energy flexibility provided by battery energy storages [12] and energy efficient technologies [13].

However, commercial buildings, especially retail stores are reluctant to shift their electricity consumption pattern to avoid any disturbances in their business operations [9, 14]. Especially, commercial buildings try to maintain customers' comfort [15] and visual quality [16]. In addition, studies show that lack of awareness [13] and lack of skilled managers on energy efficiency [17] affect the energy performance of retail stores. Although there are studies on how organizational structures and customers $[15,18]$ influence the energy management [11] and energy consumption in retail stores [19], there are still limited 


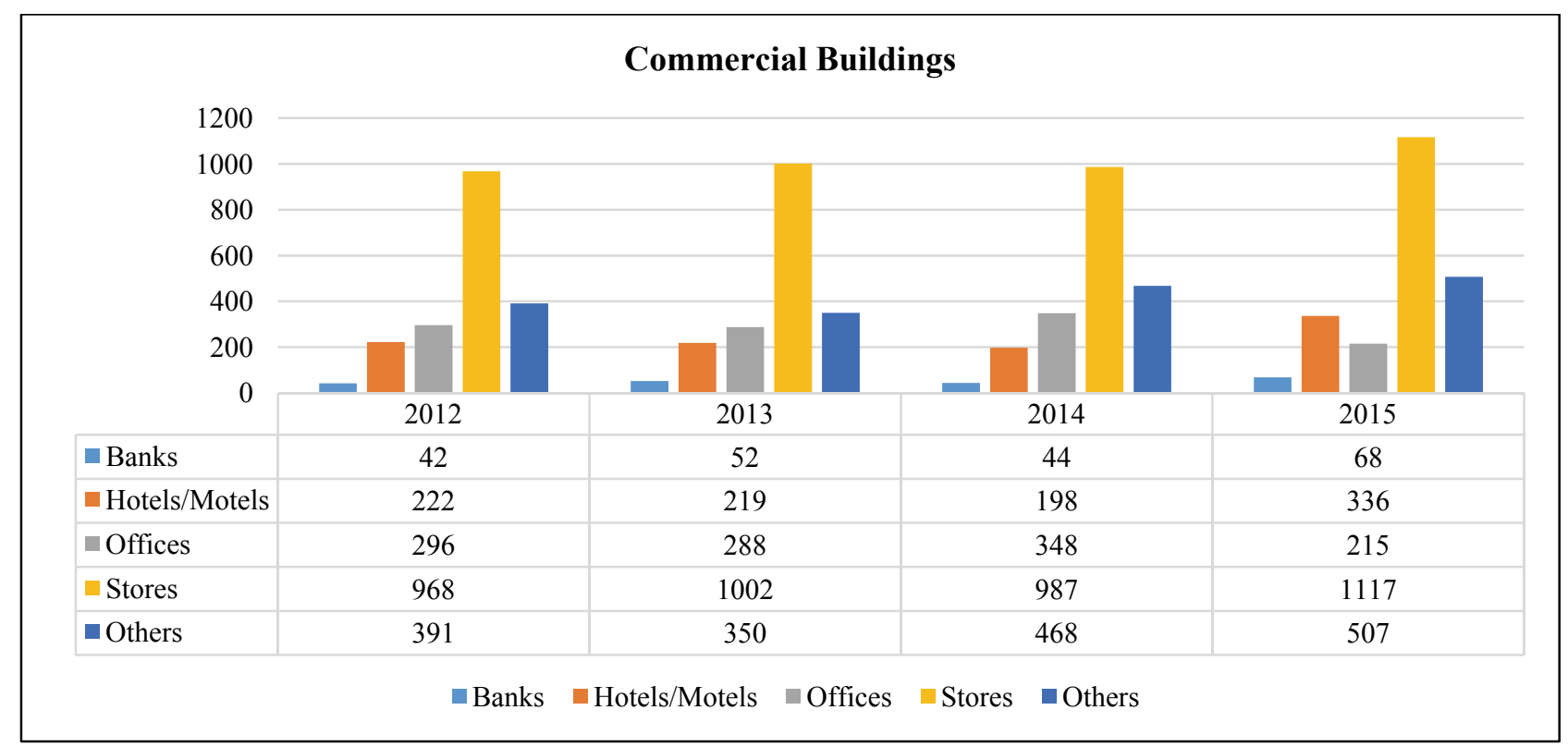

Fig. 1 Newly constructed commercial buildings in the Philippines 2012-2015 [4-7].

studies which systemically investigate internal and external factors and stakeholders' involvement in the energy management of retail buildings. Moreover, the energy management design for retail buildings requires integrated solutions with multi-perspective considerations.

Therefore, to fill this gap, this paper uses a multi-case study of retail stores in the Philippines, to develop an assessment integrating internal and external factors, internal and external stakeholders to examine the energy profiles (energy consumption, energy technologies, and energy management) in retail stores. Secondly, this paper tries to identify the roles of different stakeholders and understand their impacts on the energy efficiency and flexibility in retail stores.

The rest of the paper is organized as follows: Section 2 presents the literature review that outlines distinctive areas of energy management in retail stores. The methodology and results are discussed in Sections 3 and 4. Finally, discussion and conclusion are presented in Section 5.

\section{Literature Review}

There are three distinct areas in the literature of energy management in retail buildings: features of retail stores, energy management and technologies, and stakeholders' involvement.

\subsection{Features of Retail Stores}

Retail stores include supermarkets, convenience stores, shopping centers, department stores, and specialty stores. Shopping centers are smaller-size malls comprised of supermarkets, food courts, small shops, bakeries, cinemas, and others. Convenience stores (e.g. 7-eleven) are retail stores that provide a wide variety of consumable products [20] and usually situated in the areas close to consumers (e.g. town center, petrol stations) [21]. Department stores are retail outlets that sell a wide variety of products but smaller compared to shopping centers. Specialty stores sell specific items or limited product lines (e.g. shoes) that consider good lighting design to attract customers [16].

Retail stores vary in size, location, store functions, opening hours, building type (e.g. newly build or retrofitted) and products. For instance, convenience stores have sales floor areas of less than $280 \mathrm{~m}^{2}$ and supermarkets are between 280 to $1,400 \mathrm{~m}^{2}$ [21], while medium size shopping centers have GFA (gross floor 
areas) of $3,700 \mathrm{~m}^{2}$ to $9,300 \mathrm{~m}^{2}$ [22]. Shopping centers have a GLA (gross lease area) of $5000 \mathrm{~m}^{2}$ [15]. Furthermore, some retail stores (e.g. convenience stores) are open for business 24 hours, 7 days a week [21].

Various features can influence the energy performance of retail stores. Spyrou et al. [10] state that various influential factors affect the energy consumption in stores (e.g. supermarkets), such as business operation, store format, customer shopping activities, products, and store equipment. Product types influence the types of energy flexibility activities in retail stores [14]. Stores selling perishable products (e.g. convenience stores) are more likely to adopt energy efficiency and flexibility than stores selling non-perishable products [11]. Large retail stores (e.g. shopping centers) may hire an energy management specialist to develop energy management plans, the evaluation, and installation of energy efficient technologies [11].

\subsection{Energy Management and Technologies}

Energy efficiency in buildings means the ability of buildings to reduce energy consumption by utilizing efficient technologies or methods [23]. For example, UK supermarkets include energy efficiency to reduce their energy cost [13]. To achieve energy efficiency, buildings need effective energy management plans [24]. Building retrofit is one of the energy management practices in buildings (e.g. replacing window frames) [25]. Awareness of energy consumption and occupants' behaviors (e.g. owners, managers, tenants, and customers) can also influence energy performance in buildings [15, 23, 26]. Display windows of retail stores (e.g. clothing shops) usually have lights on at least 15 hours per day that each window can consume 750-1,500 W [16]. Retail stores can save from $10 \%$ to $40 \%$ of energy by installing energy efficient lightings such as T8, T5 bulbs and other LEDs [27, 28].
There are different energy technologies, such as energy-saving lamps (e.g. LED) BEMS (Building Energy Management System) or BAS (building automation system), renewable energy system (e.g. solar PV and energy storage) that can improve energy efficiency and indoor comfort [26, 27, 29].

BMS (Building Management System) or BAS monitor and adjust building performance, and automate building devices (e.g. heat pumps, lighting systems, and HVAC box) using wireless sensors and actuators [27, 30, 31]. BMS/BAS sensors monitor the status or condition of building appliances [28]. Smart meters are used to monitor and classify energy consumption in buildings [28].

Sustainable solutions such as distributed energy generation (e.g. wind turbine or solar PV systems) are also installed in building for different reasons, e.g. power blackout [32]. For instance, diesel generators are usually used in many countries as backup power [29].

\subsection{Stakeholders of Retail Stores}

There are internal and external stakeholders involving in retail stores' operations [14]. The main stakeholders in retail stores include owners, managers, and customers $[15,31]$. Owners/managers are interested in reducing their energy use [15] and are responsible for supervising energy management practices and retail store operations [33]. Store owners/managers are usually interested in energy-saving opportunities and energy efficiency programs to reduce energy consumption. Retail store customers refer to a group of people or individuals in the society that shop in retail stores [14].

There are stakeholders that indirectly involve in the retailer stores' energy management, such as utilities and governments. Utilities are energy suppliers to retail stores and concern profit from energy production and energy saving. Government serves as energy regulators [14]. 
Table 1 Retail stores' profiles.

\begin{tabular}{llll}
\hline Company name & Store type & Location & Respondents \\
\hline LYR marketing & Specialty store & Koronadal city & Manager \\
TLG shopper's mart & Department store & Koronadal city & Owner \\
Honda Soksargen & Specialty store & Koronadal city & Manager \\
Transcyle Marbel & Specialty store & Koronadal city & Manager \\
CITI & Specialty store & Koronadal city & Manager \\
Gaisano & Shopping center & Koronadal city & Manager \\
UNITOP & Department store & Koronadal city & Manager \\
AAA general Merchandise & Specialty store & Koronadal city & Supervisor \\
Colour land paint trade & Specialty store & Koronadal city & Supervisor \\
Tupperware Ramona & Specialty store & Koronadal city & Manager \\
Gear up auto supply & Specialty store & Koronadal city & Manager \\
Fitmart & Shopping center & General Santos city & Manager \\
\hline
\end{tabular}

\section{Methodology}

To examine the building performance concerning energy efficiency and flexibility in retail stores, this paper adopts the multiple-case research design with an exploratory and qualitative methodology [34]. There are twelve retail stores in the Philippines which are selected for this study: eight specialty stores, two department stores, and two shopping centers (shown in Table 1). The selected interviewees are store owners/managers and supervisors who deal with employees, regulators, utilities and other stakeholders (e.g. customers). Interviews are conducted during retail stores opening hours to investigate the store operations.

Data analysis in this study includes summarizing the collected data and exploring different themes. Data analysis employs both exploratory and descriptive methods to generate new ideas based on retail store owners/managers' experience and views on energy consumption and energy management. It includes analyzing store features, installed appliances, and building system technologies, energy management practices, and stakeholders' involvement (e.g. employees, government, and utilities).

\section{Results}

This study finds that store features and technology adoption determine the energy consumption of retail stores. Internal and external stakeholders influence energy strategies and plans of energy efficiency and flexibility in retail stores.

\subsection{Store Features and Energy Consumption}

Electricity consumption varies from one store to another due to the variety of store features (shown in Table 2). Retail store features include store type, ownership, product sale, opening hour, building type and size, number of employees. Most features influence the energy consumption in retail stores, only opening hour does not show a significant impact on energy consumption in retail stores.

\subsubsection{Store Types}

Types of retail stores can be categorized as specialty stores, department stores, and shopping centers. This study finds that the types of stores influence the electricity consumption. The utility company, SOCOTECO, charges electricity an average price of $11.02 \mathrm{PHP} / \mathrm{KWh}$ to retail stores. The monthly electricity bill can be classified as low (500 to 10,000 PHP), average (11,000 to 50,000 PHP), high $(51,000$ to 200,000 PHP), and very high (201,000 PHP and above).

The results (Table 3) show that three specialty stores have low electricity consumption, while shopping centers (e.g. Fitmart, Gaisano) have very 
Table 2 Store Features and energy consumption.

\begin{tabular}{|c|c|c|c|c|c|c|c|}
\hline Company name & Ownership & Products & Size $\left(m^{2}\right)$ & Opening hours & $\begin{array}{l}\text { Old/new } \\
\text { building }\end{array}$ & $\begin{array}{l}\text { No. of } \\
\text { employees }\end{array}$ & $\begin{array}{l}\text { Electricity bill per } \\
\text { month (PHP) }\end{array}$ \\
\hline LYR marketing & own & Furniture & 600 & 08:00-18:30 & new & 41 & 40,000 \\
\hline $\begin{array}{l}\text { TLG shopper's } \\
\text { mart }\end{array}$ & lease & $\begin{array}{l}\text { Clothing, home } \\
\text { improvement, appliances }\end{array}$ & 400 & 09:00 -18:00 & old & 18 & 40,000 \\
\hline Honda Soksargen & own & Motorcycle & 600 & $08: 00-17: 30$ & old & 25 & 20,000 \\
\hline Transcyle Marbel & lease & Motorcycle & 110 & 08:00-17:00 & old & 14 & 20,000 \\
\hline CITI & own & Home improvement & 7,000 & 08:00-19:00 & new & 99 & 19,000 \\
\hline Gaisano & lease & $\begin{array}{l}\text { Food products, home } \\
\text { improvements, clothing, } \\
\text { appliances, etc. }\end{array}$ & 10,000 & 09:00-19:30 & old & 255 & $2,500,000$ \\
\hline UNITOP & lease & $\begin{array}{l}\text { Home improvement, } \\
\text { kitchen appliances, } \\
\text { clothing }\end{array}$ & 600 & 08:00-20:00 & old & 51 & 200,000 \\
\hline $\begin{array}{l}\text { AAA general } \\
\text { Merchandise }\end{array}$ & lease & Kitchenware & 30 & 08:30-18:00 & new & 2 & 2,000 \\
\hline $\begin{array}{l}\text { Colour land } \\
\text { paint trade }\end{array}$ & lease & Paint & 30 & 08:30-18:00 & new & 4 & 1,000 \\
\hline $\begin{array}{l}\text { Tupperware } \\
\text { Ramona }\end{array}$ & lease & Kitchenware & 60 & 08:00-20:00 & old & 7 & 12,000 \\
\hline $\begin{array}{l}\text { Gear up auto } \\
\text { supply }\end{array}$ & lease & Motor cycle parts & 150 & 07:30-18:00 & old & 14 & 4,000 \\
\hline Fitmart & lease & $\begin{array}{l}\text { Food products, home } \\
\text { improvements, clothing, } \\
\text { appliances, etc. }\end{array}$ & 600 & 09:00-19:30 & old & 200 & 850,000 \\
\hline
\end{tabular}

PHP is the Philippines currency, pesos, 1 US dollar $=51.3$ PHP.

Table 3 Store types and energy consumption.

\begin{tabular}{ll}
\hline Types of store & Electricity consumption \\
\hline Specialty stores (3) & Low (500 to 10,000 PHP) \\
Specialty stores (6) & Average (11,000 PHP to 50,000 PHP) \\
Department store (1) & High (51,000 PHP to 200,000 PHP) \\
Shopping centers (2) & Very high (201,000 PHP and above) \\
\hline
\end{tabular}

high electricity consumption. The reason is that the products or facilities in specialty stores are much simpler compared to other types of retail stores.

\subsubsection{Ownership}

Retail stores can own or lease buildings. Table 2 shows that three retail stores (LYR, CITI and Honda Soksargen) own their buildings. The rest of the stores are the leased buildings. Some retail stores lease buildings and pay electricity bills through building owners, e.g. Tupperware Ramona. They do not directly contact utilities. Retail stores that own their buildings pay electricity bills directly to the utilities.

The results show that retail stores that own buildings pay an average amount of electricity bill
(11,000 to 50,000 PHP), while stores that lease buildings pay low, high and very high electricity. For instance, Honda that owns their buildings pays 20,000 PHP monthly. This study finds that retail stores that are directly responsible for their energy consumption concern more about energy savings.

\subsubsection{Product Types}

Variety of products sold in retail stores directly influences the electricity consumption. The results show that some retail stores only sell non-perishable products, and shopping centers sell both perishable and non-perishable products. Retail stores that sell a perishable product, e.g. food, need cooling systems and pay very high electricity consumption (e.g. 
Fitmart, Gaisano). Retail stores that sell non-perishable products consume a low amount of electricity (e.g. Gear up auto supply) to the average amount of electricity (e.g. CITI).

\subsubsection{Building Size}

The size of retail stores can be categorized as small $\left(10-100 \mathrm{~m}^{2}\right)$, average $\left(101-500 \mathrm{~m}^{2}\right)$ and large $\left(501 \mathrm{~m}^{2}\right.$ and above). This study selects four small sizes, four average sizes, and four large retail stores. The results show that the size of retail stores strongly influences electricity consumption because the building sizes influence the number of employees and customers in stores. For example, large-size retail stores (e.g. Fitmart and Gaisano) consume the very high amount of electricity, small retail stores (e.g. Tupperware Ramona, AAA General Merchandise) have low electricity consumption and average-size stores (e.g. LYR and TLG shopper's mart) have average electricity consumptions.

\subsubsection{Building Type}

Buildings types can be classified as new (0-10 years) or old (10 years and above). The results show that building types influence electricity consumption. New buildings (e.g. LYR, Honda Soksargen, CITI, AAA General Merchandise, and Colorland Paint Trade) consume low to average amount of electricity each month. Old buildings (e.g. TLG shopper's mart, Transcycle Marbel, Gaisano, UNITOP, Tupperware Ramona, Gear up Auto Supply and Fitmart) consume average to the very high amount of electricity. The main reason is due to the requirement of building codes. Newer buildings need to comply more restrict building codes for energy efficiency. Meanwhile, building retrofit or building automation is not popular in the Philippines. Therefore, old buildings have low energy efficiency.

\subsubsection{Number of Employees}

A number of employees can be categorized as few (1 to 15$)$, average (16 to 50), many (51 and above). Obviously, larger retail stores sell a wider variety of products and hire more employees than the smaller ones. For instance, retail stores (e.g. Gaisano, Fitmart) have many employees and have very high electricity consumption. Retail stores (e.g. AAA General Merchandise) have few employees and consume low to average amount of electricity.

\subsection{Technologies and Energy Consumption}

Installed technologies in retail stores consist of appliances and distributed energy resources. Store appliances are machines or devices that consume electricity for business operations. The main appliances in retail stores are air-conditioning, freezers and lightings. In addition, average and large size stores install CCTV and fire alarms to ensure security. Department stores and large shopping center install escalators for their customers. Distributed energy resources for retail stores are usually diesel generators and solar panels in the Philippines. This study also finds that energy consumption directly influences energy management practices in retail stores.

\subsubsection{Retail Store Appliances}

The types of appliances (e.g. air-conditioning units and freezers) in retail stores influence electricity consumption. For example, retail stores (e.g. shopping centers) that sell food products use freezers and coolers which consume the very high amount of electricity. Comparatively, retail stores that do not use freezers consume a minimal amount of electricity. In addition, the majority of the retail stores install air-conditioning systems due to the warm climate in the Philippines. The results of this study show, air-conditioning systems are the most electricity consuming appliances, especially in stores (e.g. department stores). Air-conditioning systems consume a large amount of electricity to balance indoor climate due to many customers' coming in and out of buildings. Customers of retail store require indoor comfort when visiting to stores: "Customers complain when it's warm inside the stores" quoted from the owner of TLG shopper's mart. 
Table 4 Appliance types and energy consumption.

\begin{tabular}{|c|c|c|c|c|c|c|c|}
\hline Company name & Air-conditioning & Freezers & Lightings & CCTV & Fire alarms & $\begin{array}{l}\text { Escalators/ } \\
\text { elevators }\end{array}$ & $\begin{array}{l}\text { Emergency } \\
\text { Diesel } \\
\text { Generator }\end{array}$ \\
\hline LYR Marketing & yes & no & $\begin{array}{l}\text { LED } \\
\text { CFL } \\
\text { Incandescent lamps }\end{array}$ & yes & yes & no & yes \\
\hline TLG shopper's mart & yes & no & $\begin{array}{l}\text { LED } \\
\text { CFL } \\
\text { Incandescent lamps }\end{array}$ & yes & yes & no & yes \\
\hline Honda Soksargen & yes & no & $\begin{array}{l}\text { LED } \\
\text { CFL } \\
\text { Incandescent lamps }\end{array}$ & yes & yes & no & yes \\
\hline Transcycle Marbel & yes & no & $\begin{array}{l}\text { Fluorescent } \\
\text { Incandescent lamps } \\
\text { LED }\end{array}$ & yes & yes & no & no \\
\hline CITI & yes & no & $\begin{array}{l}\text { CFL } \\
\text { Incandescent lamps }\end{array}$ & yes & yes & no & yes \\
\hline Gaisano & yes & yes & $\begin{array}{l}\mathrm{CFL} \\
\text { Incandescent lamps }\end{array}$ & yes & yes & yes & yes \\
\hline UNITOP & yes & no & $\begin{array}{l}\text { LED } \\
\text { CFL } \\
\text { Incandescent lamps }\end{array}$ & yes & yes & yes & yes \\
\hline $\begin{array}{l}\text { AAA General } \\
\text { Merchandise }\end{array}$ & yes & no & LED & no & no & no & no \\
\hline Color Land Paint Trade & yes & no & LED & no & no & no & no \\
\hline Tupperware Ramona & yes & no & LED & no & no & no & no \\
\hline Gear Up auto supply & yes & no & $\begin{array}{l}\text { LED } \\
\text { CFL } \\
\text { Incandescent lamps }\end{array}$ & yes & no & no & no \\
\hline Fitmart & yes & yes & LED & yes & yes & no & yes \\
\hline
\end{tabular}

The results (Table 4) show that LED lightings are the most common energy-efficient technology installed in retail stores in the Philippines. However, due to the cost of LED lighting, some retail stores still use CFL and incandescent lighting. On the other hand, some stores that lease buildings only adopt the lightings provided by building owners.

\subsubsection{Distributed Energy Resources}

Owners and managers of retail stores are familiar with solar panels. There are companies that visit retail stores and demonstrate solar panels and solar panel systems to local stores (e.g. CITI). However, the results show that none of the retail stores installs solar panels in this study. A specialty store manager claims "We are selling solar panels but we don't use it", because of the high investment of solar panels.

Meanwhile, average and large-size retail stores install diesel-powered emergency generators.
However, diesel generators cannot always handle all types of appliances for long hours, and it affects store operations. Some shopping centers use generators provided by building owners. A shopping center manager states: "We just lease buildings from $\mathrm{RD}$ Company. During a power blackout, we wait for the building owner to start the generator that is shared by different tenants. It takes some time to start the diesel generator and that give negative feedback from store customers. The generation capacity is divided among building tenants. When there is not enough power supply from the generator, the building owner would advise us to turn off some of our appliances".

\subsubsection{Energy Management Practices}

Energy consumption affects the energy management practices in retail stores. The results show, shopping centers that consume the very high amount of electricity have a higher interest in 
energy-savings. The most common energy-saving practices in retail stores are monitoring and control of electrical appliances (e.g. turning off unnecessary appliances) and installing LED lighting. Some of the retail stores consider skylights and insulation to reduce electricity consumption. For instance, CITI that owns buildings designs buildings with skylights and insulation.

Very high electricity consumption encourages shopping centers (e.g. Gaisano and Fitmart) to include energy management in their daily store operations. For instance, during the daily line information of shopping center crews, store managers instruct employees about the energy-saving rules of the company and assign a responsible staff to turn off unnecessary equipment. In addition, during weekdays shopping centers operate escalators late (e.g. 12 noon) when there are few customers, and turn off air-conditioning units one hour before the closing time.

The results of this study (in Table 5) show that there are four energy management practices in retail stores in general:

- Monitor and control appliances

- Use natural lighting

- Install LED lighting
- Use skylights and insulation

- Setup energy management policies and energy-saving rules

\subsection{Stakeholders' Involvement in Energy Management}

Retail store owners/managers are responsible for energy management implementation (shown in Table 6). Meanwhile, the internal stakeholders (e.g. employees) and external stakeholders (e.g. utilities and governments) also influence the energy management in retail stores.

4.3.1 Employees' Involvement

Employees' involvement in the energy management varies from one retail store to another (shown in Table 7). Electricity consumption influences how retail stores encourage their employees for energy saving. Retail stores that pay higher electricity bill concern more about electricity consumption. Therefore, managers/owners encourage their employees to save energy. For example, shopping centers (e.g. Fitmart and Gaisano) pay the very high amount of electricity, and the store managers remind their employees daily for energy saving. Meanwhile, they also set up company rules to highly involve employees in energy management practices.

Table 5 Energy management practices in retail stores.

\begin{tabular}{|c|c|}
\hline Retail stores & Practices \\
\hline LYR & $\begin{array}{l}\text { We minimize the use of air-conditioning and install circuit breakers for our computers. We also use } \\
\text { LED lightings. }\end{array}$ \\
\hline TLG & $\begin{array}{l}\text { We install LED lightings. I just turn off all the lights when there are not many customers. Cleaning } \\
\text { and maintenance of air-conditioning also can reduce energy consumption. }\end{array}$ \\
\hline Honda Soksargen & Yes, we replace our lightings with LED and turn off unnecessary appliances. \\
\hline Transcycle Marbel & We turn off unnecessary appliances. \\
\hline CITI & We use skylights and insulation, and control the use of lightings and air-conditioning. \\
\hline Gaisano & $\begin{array}{l}\text { We advise them to control and schedule the use of air-conditioning, escalators, lightings and freezer } \\
\text { temperature. We have maintenance and cleaning of the air-conditioning. We turn off } \\
\text { air-conditioning one hour before store closing. }\end{array}$ \\
\hline UNITOP & We control the use of lightings and air-conditioning and other appliances. \\
\hline AAA General merchandise & $\begin{array}{l}\text { Turn off the air-conditioning when there is no customer, and we use natural lightings. We only use } \\
\text { air-conditioning when we have meetings with Tupperware dealers. }\end{array}$ \\
\hline Color land Paint trade & The owner controls the use of electrical devices such as air-conditioning and water dispenser. \\
\hline Tupperware Ramona & We just turn off unnecessary electrical devices. \\
\hline Gear up Auto supply & Nothing much, we just turn off electrical appliances when they are not in use. \\
\hline Fitmart & $\begin{array}{l}\text { We strictly implement energy-saving policies to employees, we schedule the use of lightings and } \\
\text { turn off unnecessary appliances (e.g. 18:30 turn off the air-conditioning) }\end{array}$ \\
\hline
\end{tabular}


Table 6 Responsible roles for energy management in retail stores.

\begin{tabular}{ll}
\hline Retail stores & Responsible persons \\
\hline LYR & Manager \\
TLG & Owner \\
Honda Soksargen & Manager \\
Transcycle Marbel & Manager \\
CITI & Manager \\
Gaisano & Manager \\
UNITOP & Manager \\
AAA General merchandise & Manager \\
Color land Paint trade & Supervisor \\
Tupperware Ramona & Owner \\
Gear up Auto supply & Manager \\
Fitmart & Manager \\
\hline
\end{tabular}

Retail stores that do not include energy management in the store policies acquire a low level of employees' involvement. For instance, the owner of TLG shopper's mart states: "No, our employees don't really care. It's me who do things to save electricity".

\subsubsection{Governments' Involvement}

The results in this study show that government does not highly involve in energy practices of retail stores. The twelve retail stores in this study all situated on the same island. Therefore, most retail stores are under the same government administration. The results show that retail stores have low awareness of any financial incentive or energy program provided by the government. In addition, governmental energy programs are not mandatory. It shows that the government does not provide enough support for energy efficiency.

\subsubsection{Utilities' Involvement}

Koronadal city experiences brownouts at least once a week. SOCOTECO is an electric cooperative and the only electricity distributor in Koronadal city. SOCOTECO informs the public about scheduled brownouts through different media channels (e.g. radio, SMS and Facebook), and retail stores can prepare backup diesel-powered generation.

Electricity blackout has a negative impact on the shopping activities of customers. "Customers are upset if no power because it's so warm"- - owner of TLG shopper's mart. SOCOTECO has low encouragement to consumers for energy saving. Only large energy consumers (e.g. Gaisano, Fitmart) receive information from utilities regarding the reduction of electricity consumption. Table 8 shows that electricity consumers are not fully aware of utilities' energy-saving programs.

Table 7 Employees' involvement in energy management.

\begin{tabular}{ll}
\hline Retail stores & Involvement in energy management \\
\hline LYR Marketing & No, employees are purely for work. \\
TLG shopper's mart & No, they do not care. \\
Honda Soksargen & Yes, they should participate. \\
Transcycle Marbel & Yes, employees are involved. The management always reminds employees and it is in the store \\
& policies. \\
CITI & Yes, because it is part of the rules and regulation. I include that during the daily meeting before the \\
Gaisano & store opening. \\
UNITOP & Yes, they are involved. Energy-saving rules are strictly implemented by the management. \\
AAA General Merchandise & We remind them but they just care about their work. \\
Color Land Paint Trade & No, we don't really care. \\
Tupperware Ramona & No, we are busy at work. \\
Gear Up Auto Supply & No, not really, we are busy in the store. \\
Fitmart & Yes, they are highly involved because I remind them during the line meeting every day. \\
\hline
\end{tabular}


Table 8 Utilities' involvement in Energy management.

\begin{tabular}{lll}
\hline Retail store & Power interruption/blackout & Energy saving tips \\
\hline LYR marketing & Yes, they inform when there is scheduled power blackout & $\begin{array}{l}\text { Yes, energy saving tips attached to } \\
\text { the bills }\end{array}$ \\
TLG shopper's mart & Yes, they inform through radio during the scheduled blackout & No \\
Honda Soksargen & Yes, we got information from SOCOTECO through radio and & No \\
Transcycle Marbel & text messages & No \\
CITI & Yes, they inform through radio & No \\
Gaisano & Yes, we know because they inform & Yes \\
UNITOP & Yes & No \\
AAA General Merchandise & Yes, through radio and Facebook & No \\
Color land Paint trade & Yes & No \\
Tupperware Ramona & Yes & No \\
Gear up Auto supply & Yes, through Facebook when there are scheduled brownouts & No \\
Fitmart & Yes & Yes \\
\hline
\end{tabular}

\section{Discussions}

The results in this study show that store features, such as size, store appliances, types of stores, products, ownership, building types, ownership and number of employees, influence energy consumption of retail stores. For instance, products and services can influence the types of appliances installed in retail stores, which can influence the electricity consumption. The study also finds that retail stores selling perishable are more willing to adopt energy efficient and flexible solutions than stores selling non-perishable products. This paper finds the reason that retail stores which install freezers and air-conditioning units pay higher electricity bills. However, the opening hours do not show a significant impact on the energy consumption, because there are no twenty-four-hour stores in the study, and the differences in opening hours among selected stores are not significant.

This study finds a similar result as Ref. [14] that, in the Philippines, owners/managers concern about reducing energy consumption, and are responsible for supervising the energy management practices and managing the retail store operations. The study shows that owners/managers in retail stores in the Philippines are not fully skilled, and they lack awareness on energy efficiency. This study finds that the electricity price in the Philippines is the highest in Asia, and retail stores' owners/managers consider energy-savings due to high electricity consumption. Furthermore, this study discovers that setting company rules is the most effective solution applied to employees to practice energy saving in retail stores.

On the other hand, this paper finds that external factors such as electricity price, customers' behavior, and climate can influence electricity consumption in retail stores. Retail stores located in a warm climate region require more electricity, especially during the summer months, to maintain the indoor temperature. Awareness of energy consumption and occupants' behaviors (e.g. owners, managers, tenants and customers) can also influence energy performance in buildings. This study finds that customers affect the retail stores' energy behavior. For instance, retail stores in the Philippines need to install air-conditioning units to satisfy their customers with good indoor temperature.

The impacts of regulation and utilities on energy management in retail stores are not significant in this paper, which is different from other countries. The government has a weak role in the smart energy development in the Philippines, and utilities mainly dominate the smart grid development. So far, utilities have few incentives to improve energy efficiency or flexibility at the consumption side. 
Studies suggest that installing a BAS for monitoring energy performance can increase energy efficiency in buildings [30, 31, 35]. However, this study finds that retail stores in the Philippines are not equipped with BMS or BAS due to the high cost of technologies and maintenance. Literature shows that retail stores can save from $10 \%$ to $40 \%$ of energy by installing energy efficient lightings such as T8, T5 bulbs and other LEDs [27, 28]. The results in this study show that, although the installation of LED lightings is common energy efficiency upgrades for retail stores, it depends on whether the retail buildings are rented or owned by the retail stores.

There are two types of energy flexibility applied in retail stores in the Philippines with different reasons: (1) Retail stores practice energy flexibility by adjusting the indoor temperature and turning off machines when not in use due to high electricity consumptions. (2) The frequent power outage in the Philippines influences retail stores' business operations. Retail stores usually use diesel-fuelled generators to deal with the lack of electricity supply.

\section{Conclusions}

There are huge potentials for retail stores to gain benefits from energy efficiency and flexibility due to large energy consumption and building control systems. Yet effective plans and implementation of such strategies face significant challenges due to disturbances in their business operations. Based on the results, this study develops an assessment for retail stores. The assessment guideline can assist retail stores to develop their energy management plans in a nation like the Philippines. The assessment includes: store features, internal and external stakeholders, climate and grid condition, energy consumption and management (shown in Fig. 2).

This study makes two major contributions to the existing literature. First, our findings contribute to establishing systematic evacuation of retail stores' profile, and the correlation with energy management strategies for retail stores. Meanwhile, this study adds to the literature by discussing the impacts of external factors (climate, grid condition, and price signals) to store profile and energy management strategies. Second, our study integrates the internal and external stakeholders' involvement in the energy management. The strong roles of stakeholders influence the retail stores' energy management different, and it varies across nations.

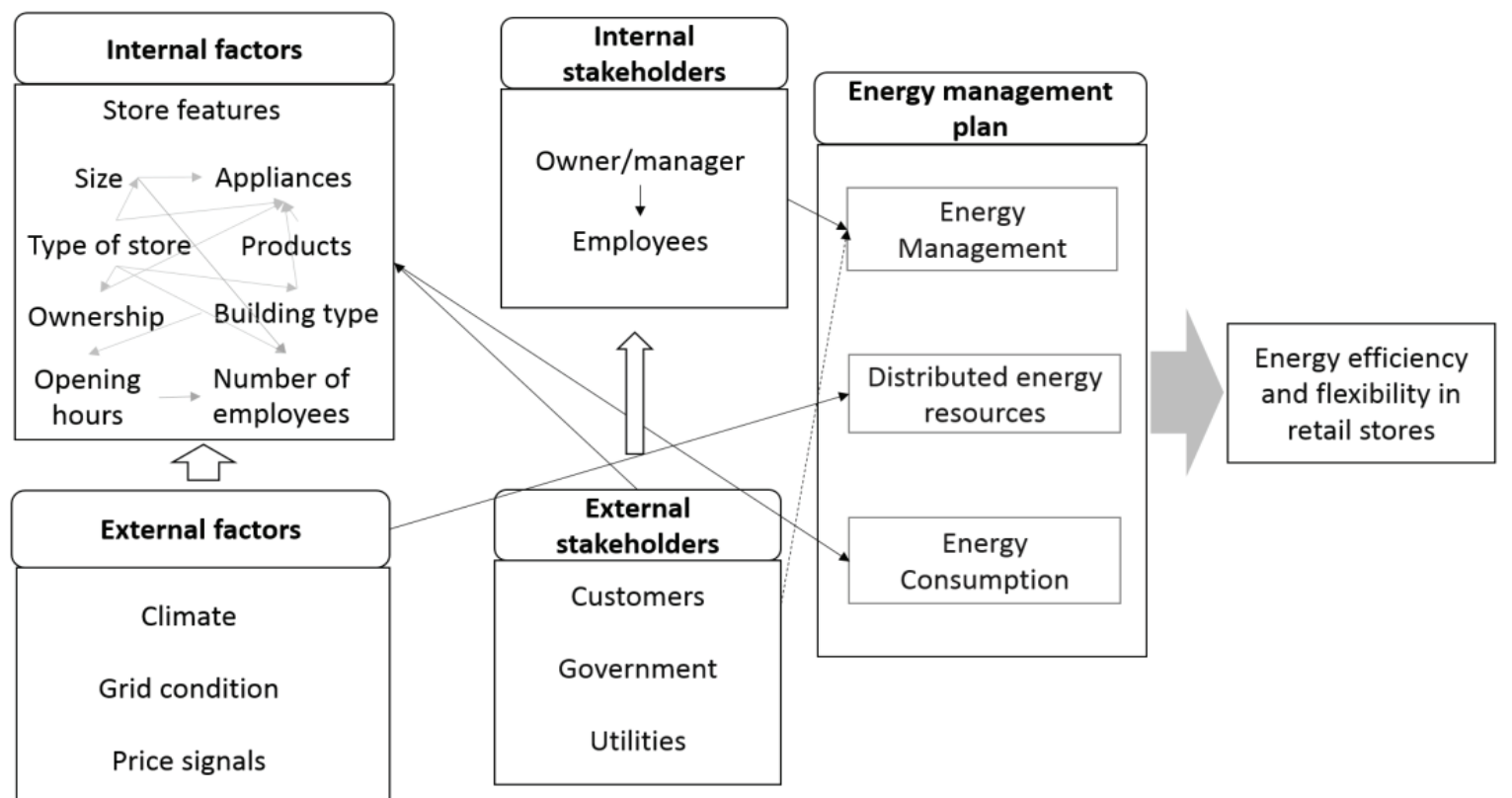

Fig. 2 Assessment of energy management plan in retail stores. 
Due to the constraints of our data, this study suffers some limitations. First, the results only represent the retail stores in the Philippines. There are cross-national differences, such as climate, power grid condition, and price signals. Meanwhile, the role of government and utilities are different in each country. Therefore, this study suggests the future research should include the cross-national comparison. Second, the energy flexibility in this study only represents countries like the Philippines where the power grid is unstable and there is no demand response scheme. Therefore, this study suggests the demand response and distributed energy resources (e.g. storages and renewable energy sources) can be discussed in the future research.

\section{References}

[1] Schachinger, D., Gaida, S., Kastner, W., Petrushevski, F., Reinthaler, C., Sipetic, M., et al. 2016. "An Advanced Data Analytics Framework for Energy Efficiency in Buildings.” In 2016 IEEE 21st International Conference on Emerging Technologies and Factory Automation (ETFA), pp. 1-4.

[2] Ma, Z., Billanes, J. D., Kjærgaard, M. B., and Jørgensen, B. N. 2017. "Energy Flexibility in Retail Buildings: From a Business Ecosystem Perspective." In 2017 14th International Conference on the European Energy Market (EEM), Dresden, Germany, p. 6.

[3] Zhao, J., Zhu, N., and Wu, Y. 2009. "The Analysis of Energy Consumption of a Commercial Building in Tianjin, China." Energy Policy 37: 2092-7.

[4] Philippine Statistics Authority. 2012. Number of New Commercial Building Construction Started, Floor Area and Value of Constructions, by Type and by Province: Fourth Quarter, 2012. Edited by S. D. Office. Philippines: Philippines Statistics Authority.

[5] Philippine Statistics Authority. 2013. TABLE 4 Number, Floor Area and Value of New Commercial Buildings by Type and by Province: 4th Quarter, 2013. Edited by P. S. Authority, Philippines, p. 6.

[6] Philippine Statistics Authority. 2014. TABLE 4 Number, Floor Area and Value of Commercial Building Constructions, by Type and by Province: Fourth Quarter. Philippines: Philippine Statistics Authority, p. 6.

[7] Philippine Statistics Authority. 2015. TABLE 4 Number, Floor Area and Value of Commercial Building Constructions by Type and by Province: Fourth Quarter.
Philippines: Philippines Statistics Authority, p. 6.

[8] Furuto, A. 2011. First Certified "Green" Project in the Philippines/Oppenheim Architecture + Design. Available: http://www.archdaily.com/113884/first-certified-green-pr oject-in-the-philippines-oppenheim-architecture-design.

[9] Connell, N. O., Madsen, H., Pinson, P., Malley, M. O., and Green, T. 2014. "Regulating Power from Supermarket Refrigeration." In IEEE PES Innovative Smart Grid Technologies, Europe, 2014, pp. 1-6.

[10] Kolokotroni, M., Tassou, S. A., and Gowreesunker, B. L. 2015. "Energy Aspects and Ventilation of Food Retail Buildings." Advances in Building Energy Research 9: 1-19.

[11] King, R. P., Seltzer, J., and Poppert. W. The 2001 Supermarket Panel Energy Management Study. 47. Available:

http://ageconsearch.umn.edu/bitstream/14332/1/tr03-03.p df.

[12] Ota, J. I. Y., Sato, T., and Akagi, H. 2016. "Enhancement of Performance, Availability, and Flexibility of a Battery Energy Storage System Based on a Modular Multilevel Cascaded Converter (MMCC-SSBC).” IEEE Transactions on Power Electronics 31: 2791-9.

[13] Ochieng, E. G., Jones, N., Price, A. D. F., Ruan, X., Egbu, C. O., and Zuofa, T. 2014. "Integration of Energy Efficient Technologies in UK Supermarkets." Energy Policy 67: 388-93.

[14] Ma, Z., Billanes, J. D., Kjærgaard, M. B., and Jørgensen, B. N. 2017. "Energy Flexibility in Retail Buildings: From a Business Ecosystem Perspective." Presented at the 2017 14th International Conference on the European Energy Market (EEM), Dresden, Germany.

[15] Woods, R., Skeie, K. S., and Haase, M. 2017. "The Influence of User Behaviour on Energy Use in European Shopping Centres." Sustainable Development 25: 11-24.

[16] Freyssinier, J. P., Frering, D., Taylor, J., Narendran, N., and Rizzo, P. 2006. "Reducing Lighting Energy Use in Retail Display Windows.” pp. 63371L-11.

[17] Cai, J., Lin, Y., and Feng, Y. 2009. "Improving Energy-Efficiency in Public Buildings in China: Challenges and Solutions." In 2009 International Conference on Computational Intelligence and Software Engineering, pp. 1-5.

[18] Christina, S., Dainty, A., Daniels, K., and Waterson, P. 2014. "How Organisational Behaviour and Attitudes can Impact Building Energy Use in the UK Retail Environment: A Theoretical Framework." Architectural Engineering and Design Management 10: 164-79.

[19] Tassou, S. A., Ge, Y., Hadawey, A., and Marriott, D. 2011. "Energy Consumption and Conservation in Food Retailing." Applied Thermal Engineering 31: 147-56. 
[20] Miwa, K., and Takakuwa, S. 2008. "Simulation Modeling and Analysis for In-Store Merchandizing of Retail Stores with Enhanced Information Technology." In 2008 Winter Simulation Conference, pp. 1702-10.

[21] Spyrou, M. S., Shanks, K., Cook, M. J., Pitcher, J., and Lee, R. 2014. "An Empirical Study of Electricity and Gas Demand Drivers in Large Food Retail Buildings of a National Organisation." Energy and Buildings 68: 172-82.

[22] Richman, R., and Simpson, R. 2016. "Towards Quantifying Energy Saving Strategies in Big-Box Retail Stores: A Case Study in Ontario (Canada)." Sustainable Cities and Society 20: 61-70.

[23] Pan, J., Jain, R., and Paul, S. 2014. "A Survey of Energy Efficiency in Buildings and Microgrids Using Networking Technologies." IEEE Communications Surveys \& Tutorials 16L: 1709-31.

[24] Alhurayess, S., and Darwish, M. K. 2012. "Analysis of Energy Management in Hospitals." In 2012 47th International Universities Power Engineering Conference (UPEC), pp. 1-4.

[25] Gordo, E., Campos, A., and Coelho, D. 2011. "Energy Efficiency in a Hospital Building Case Study: Hospitais da universidade de Coimbra." In Proceedings of the 2011 $3 r d$ International Youth Conference on Energetics (IYCE), pp. 1-6.

[26] Arditi, D., Mangano, G., and Marco, A. D. 2015. "Assessing the Smartness of Buildings." Facilities 33: 553-72.

[27] Pellegrino, A., Verso, M. L., Blaso, L., Acquaviva, A., Patti, E., and Osello, A. 2015. "Lighting Control and Monitoring for Energy Efficiency: A Case Study Focused on the Interoperability of Building Management Systems." In 2015 IEEE 15th International Conference on
Environment and Electrical Engineering (EEEIC), pp. 748-53.

[28] Basuroy, S., Chuah, J. W., and Jha, N. K. 2013. "Making Buildings Energy-Efficient through Retrofits: A Survey of Available Technologies." In 2013 IEEE Power \& Energy Society General Meeting, pp. 1-5.

[29] Saurav, K., Bansal, H., Nawhal, M., Chandan, V., and Arya, V. 2016. "Minimizing Energy Costs of Commercial Buildings in Developing Countries.” In 2016 IEEE International Conference on Smart Grid Communications (SmartGridComm), pp. 637-42.

[30] Guglielmo, D. D., and Anastasi, G. 2012. "Wireless Sensor and Actuator Networks for Energy Efficiency in Buildings." In 2012 Sustainable Internet and ICT for Sustainability (SustainIT), pp. 1-3.

[31] Ma, Z., Billanes, J. D., and Jørgensen, B. N. 2017. “A Business Ecosystem Driven Market Analysis: The Bright Green Building Market Potential.” Presented at the IEEE TEMSCON 2017, Silicon Valley (Santa Clara), California USA.

[32] Hijjo, M., Bauer, P., Felgner, F., and Frey, G. 2015. "Energy Management Systems for Hospitals in Gaza-Strip." In 2015 IEEE Global Humanitarian Technology Conference (GHTC), pp. 18-25.

[33] Comer, E. H. 2008. "Transforming the Role of Energy Efficiency." Natural Resources \& Environment 23: 34-8.

[34] Harris, S. G., and Sutton, R. I. 1986. "Functions of Parting Ceremonies in Dying Organizations." The Academy of Management Journal 29: 5-30.

[35] Targosz, R. 2011. "Increasing Energy Efficiency in Buildings through Building Automation Measures-Role of Demonstration." In 11th International Conference on Electrical Power Quality and Utilisation, pp. 1-4. 